\title{
STUDENT PREPAREDNESS TOWARD MOUNT MERAPI ERUPTION IN SD NEGERI LENCOH IN SELO SUB DISTRICT
}

\author{
Ratih Puspita Dewi ${ }^{1}$, Muhammad Hafidhudin Anwar ${ }^{2}$, Hayatun Nupus ${ }^{3}$ \\ Universitas Muhammadiyah Surakarta \\ e-mail: rpd229@ums.ac.id
}

\begin{abstract}
Schools are one of vulnerable public places in case of disaster phenomenon. On the other side, school is a place where the children spend most of their time. It is possible that volcanic eruption occur while children study at school. Selo is one of the sub district of Boyolali district that located on the north side of Mount Merapi, its location is quite close to the peak of Mount Merapi, it is makes Selo is prone to be affected by Mount Merapi eruption. The aim of this research was to determine the level of student preparedness toward Mount Merapi eruption in SD Negeri Lencoh. The method used in this research was descriptive qualitative. The population in this research were elementary students in the high grade with consideration that student in the high grade were better in understanding to fill out the questionnaire. The sampling technique was purposive sampling technique. The data collection technique was using questionnaire developed by LIPI. The result of this research was the value of student preparedness level in SD Negeri Lencoh which was 52.1 so it was conlude as less ready.
\end{abstract}

Keywords: Preapredness, Merapi eruption, elementary student

\section{A. INTRODUCTION}

Recently, Indonesia faces many natural disaster such as floods, landslides, earthquakes, tsunamis and volcanic eruptions. This natural disaster is unpredictable it can happen everytime with or without warning including the volcanic eruptions. One of the most active volcanoes in Indonesia is Mount Merapi. Based on the administrative location, the south side slope is in the Sleman and Klaten District, west side is in the Magelang District, north and east side are in Boyolali District. As one of the most active volcano, Mount Merapi has potential volcanic hazard that endanger people who live around the slopes of Mount Merapi. According to Kusky (2008), volcanic erupstions are associated with a series of dangers that are accounted for the event of casualties and damage during eruptions. An understanding of the perceived dangers of each of these dangers can save lives and reduce the loss of property during the eruptions.

The slopes of Mount Merapi are inhabited by more than 225.000 
inhabitants. Mount Merapi has a short eruptions period of four to five years, so local people are used to live in harmony with Mount Merapi. They assume the eruption of Mount Merapi as a natural phenomenon. Mount Merapi brings blessing, a fertile land, tourism, clean water, forest and much more. (Hartono, 2015).

The volcanic eruptions produce a number of disasters such as lava, pyroclastic fall, pyroclastic spike, lateral explosion, debris avalanche, volcanic tsunami, mud, flood and gas (Pratama, 2014). Although people in the slopes of Mount Merapi are already familiar with the eruptions of Mount Merapi, but the impact caused by this phenomenon is quite large perceived by the people on the slopes of Mount Merapi including the loss of property, the destruction of agricultural areas, the destruction of houses or settlements, the destruction of farms and economic activity. To reduce and prevent the negative impact of disasters, disaster preparedness is needed for the community and school is no exception.

The world conference on disaster risk reduction held in Kobe Japan resulted a global platform for disaster risk reduction which is the Hyogo Framework for Action/HFA 2005 - 2015. In this context, the preparation of preparedness at the school level is a manifestation of the implementation of the framework. School is a place where children spend most of their time, it is possible that the Mount Merapi eruption occur when the children at school, therefore children should be protected and their knowledge of disaster in their surrounding need to be increased, which in this context, student should have a good disaster preparedness.

According to Saptadi and Djamal (2012), preparedness is a series of activities that undertaken to anticipate disaster phenomenon through organizing and also trough appropriate and efficient steps. According to Rao, et al (2007), disaster preparedness includes an actions taken before the disaster by problems anticipating in response and disaster recovery. The actions includes workshop and training to improve the readiness, development, dissemination, trial and maintenance of systems used in disaster management, as well as public education and information programs for individuals, households, companies, and public agencies. 
Selo sub district is one of the districts in Boyolali district, located on the slopes of Mount Merapi and close to the peak of Mount Merapi. In this case, people in Selo sub district should have a good disaster preparedness. Also for students they should have a good preparedness. Children is one of vulnerable aspect when facing the disaster phenomenon. This research aims to determine the level of preparedness of students in SD Negeri Lencoh.

\section{B. METHOD}

This research used a descriptive qualitative approach. The data collection technique used questionnaire and by observation. The design of this research was a case study to asses the level of students preparedness in SD Negeri Lencoh. The questionnaire used in this research was the disaster preparedness questionnaire that developed by LIPI in 2006. The determined respondent filled out the questionnaire with a guidance because some students might be did not know some part in the questions. The completed questionnaire were analyzed by scoring for each preparedness parameters. The result would show the categories for each level of students disaster preparedness.

The sampling technique used in this research was purposive sampling. The respondent was students in the high grade because they have better understanding in filling out the questionnaire than the students in the level below. The variables in this research were the level of preparedness consist of 5 parameters developed by LIPIUNESCO/ISDR (2006), which are: (1) Knowledge and attitude to disaster disaster risk, (2) Policies and guidance related to preparedness to anticipate natural disaster, (3) Plan for natural disaster emergency, (4) Disaster early warning system, (5) Resource mobilization. In this research, only used 4 paramaters, parameters on policies and guidance relate to peapredness were not use. The level of preparedness will be classified into five categories as follows:

Table 1. Classification levels of preparedness

\begin{tabular}{|c|c|}
\hline Index value & Category \\
\hline $80-100$ & Very ready \\
\hline $65-79$ & Ready \\
\hline $55-64$ & Almost ready \\
\hline $40-54$ & Less ready \\
\hline Kurang dari 40 (0-39) & Unready \\
\hline
\end{tabular}


C. RESULT

The result of this research show that the level of student preparedness in SD
Negeri Lencoh is classified into less ready category, value of each parameter as follows:

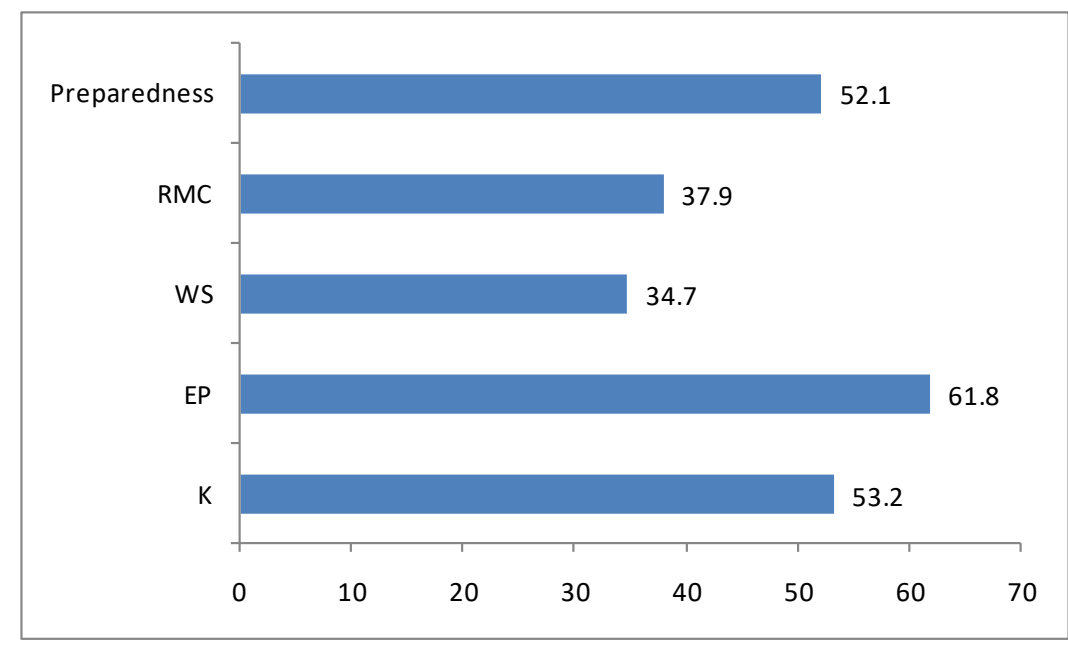

Figure 1. Student's Preparedness toward Mount Merapi Eruption

The result show that student preparedness of Mount Merapi at 52.1 so it is classified as less ready category its means that students do not know the type, symptoms, and what needs to be done if a natural disaster occurs. The value of preparedness index on the disaster knowledge and attitude (K) is 53.2, The disaster emergency plan (EP) is 61.8, the disaster early warning system (WS) is 34.7 and resources mobilization (RMC) is 37.9. The lowest index is disaster early warning system and the highest score is the disaster emergency plan.

The analysis of each parameters of preparedness show the level of knowledge and attitude of the Mount Merapi eruption is quite good, it is seen from the number of students who answered the questions correctly by $53.1 \%$. In terms of what is disaster, $89.4 \%$ students answer that volcanic eruption is a natural phenomenon that can caused damage to nature. In the case of natural phenomenon that can cause disaster, causes and kinds of following natural disaster after volcanic eruption, 50.8\% students answer correctly. More than half students answer that Mount Merapi eruption can be predicted and answers the sign of strong Mount Merapi eruption correctly. 


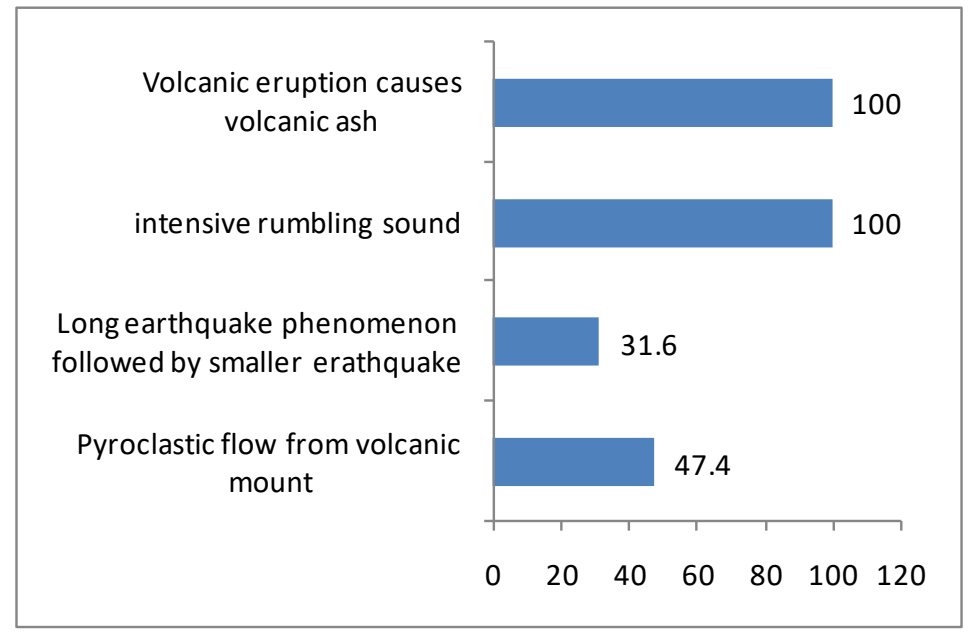

Figure 2. The Percentage of Student's Answer of Strong Mount Merapi Eruption

Further analysis about what students do when volcanic eruption occur are sheltered in a safe place, wear masks, and stay in distance from the valley by $58.3 \%$, whereas few other answer wearing long cloths and hat, close the door's house if no evacuation orders, covering face with hands, choosen lighting is flashlight, wear protective googles, and check for any injuries. $57.9 \%$ students answer that every eruptions cause lava. In terms of what causes of volcanic eruption by $50 \%$ students answer do not know what the causes. 75\% students correctly answer

Most students quite good at disaster emergency plan, by $32 \%$ attend the training about disaster rescue, $100 \%$ knowing the safe place, $73.7 \%$ note the addresses of important phone numbers of what to do for disaster preparedness. Students get the knowledge about disaster most from radio and television, printed media, schools, and also books, comics, posters, leaflets, and bulletin boards. $42.1 \%$ student experience learning about volcanic eruption and by 52.65 students experience learning about lava/pyroclastic/volcanic ash. $63.2 \%$ students experience learning about early warning system and first aid, by $73.7 \%$ experience learning about rescue and evacuation. Student discuss volcanic eruption with their friends or family by $89.5 \%$

family and relatives, by $94.7 \%$ know where to evacuate family members. Most student correctly answer for what to be safe if natural disaster occur. Most student get the information about 
volcanic eruption from books that provided by school. School already have maps and evacuation routes, evacuation/rescue equipment, first aid kit and essential medicines, and also school health posts and many of them do not aware of any disaster preparedness groups in the school.

Altough the student's knowledge and attitude towards disaster is quite good but not quite good in early warning system parameter. More than half students do not know sign for volcanic eruption warning system. Most Students know the action when the disaster occur but $94.8 \%$ of them do not know the sign if warning system is canceled. $52.6 \%$ of students are not aware of any information if the situation is safe after the volcanic eruption. More than $60 \%$ of them do not know the instrument/signs/sounds for volcanic eruption, the difference of alert/sound for warning, cancellation and safe condition from disaster. Even 100\% students never attend disaster warning/simulation drills.
Beside in early warning system parameters, the resources mobilization parameter is not quite good also. More than half students never attend first aid training, teen red cross including teenage doctor. $63.2 \%$ never attend scouting activity (making bond from ropes, building tents, making stretchers) and also most of them never attend evacuation training and simulation. Half of them never attend seminar/lecture about disaster. And $47.45 \%$ of them never tell their knowledge and skill to their friends/family.

Based on the earlier description, it can be conclude that students preparedness in early warning system and resources mobilization is not as good as in the knowledge and attitude, and disaster emergency plan. Students preparedness need to be improved for each parameters, as the result it can reduce the vulnerability aspect of students in the disaster risk reduction. In general, the level of students preparedness can be classified as follows: 


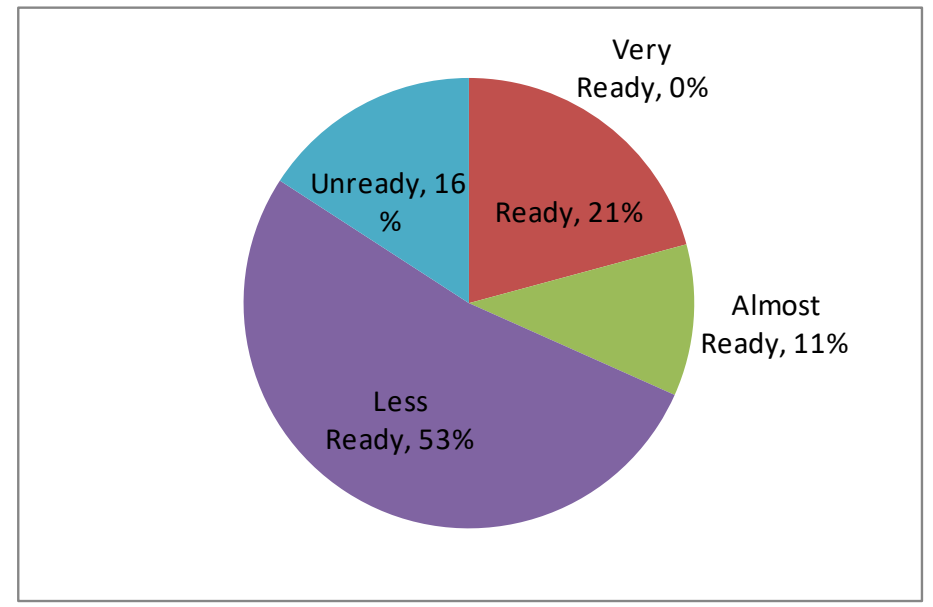

Figure 3. Classification of student prepareddness level

The figure shows the classification of student preparedness level, by $53 \%$ of them are less ready, $21 \%$ of them are ready, $16 \%$ of them are unready, $11 \%$ of them are almos ready, and no one is very ready. Eventhough $21 \%$ of them are ready, but in disaster.

\section{CONCLUSION}

The students preparedness level toward Mount Merapi eruption is classified as less ready by 52.1 . The lowest level is early warning system and the second lowest is resources mobilization. The highest is disaster emergency plan and also in knowledge and attitude parameters. Natural disaster occur at any time with or without warning so, it is essential to improve students preparedness as the result they will ready when the disaster occur at any moment. risk reduction it is important that every students are very ready facing the disaster which in this context is Mount Merapi eruption. Eventually, it can be conlude that students preparedness level in SD Negeri Lencoh is classified as less ready.

\section{E. REFERENCE}

Kusky, Timothy. 2008. Volcanoes (Eruptions and Other Volcanic Hazard). New York: Fact On File.

LIPI-UNESCO/ISDR. 2006. Kajian Kesiapsiagaan Masyarakat dalam Mengantisipasi Bencana Gempa Bumi \& Tsunami. Jakarta: LIPI.

Hartono, Mimin Dwi. 2015. Pendekatan Berbasis HAM dalam Kebijakan Rehabilitasi dan Rekonstruksi Pasca Erupsi Gunung Merapi. Jurnal Penanggulangan Bencana, Vol 6, 42-51.

Pratama, Arliandy, dkk. 2014. Pemodelan Kawasan Rawan Bencana Erupsi Gunung Api 
Berbasis Data Penginderaan Jauh (Studi Kasus di Gunung Api Merapi). Jurnal Geodesi UNDIP, Vol 3, 117-123.

Rao, Ramesh R., Et al. 2007. Improving Disaster Management: The Role of IT in Mitigation, Preparedness, Response, and Recovery. Washington D.C.: The National Academies Press. 